\title{
Agronomic Performance in Acid Soils of Wheat Lines Selected for Hematoxylin Staining Pattern
}

\author{
Norma A. Ruiz-Torres, Brett F. Carver, ${ }^{*}$ and Robert L. Westerman
}

\begin{abstract}
Laboratory screening techniques enable detection of varying degrees of Al tolerance during seedling development, but their application to crop improvement programs must be verified in the field. The objective of this study was to compare agronomic responses of wheat (Triticum aestivum L. emend. Thell.) lines differing in hematoxylin-staining pattern under naturally acidic and limed field conditions. Experiments were conducted on Bethany-Kirkland (fine, mixed, thermic Pachic-Udertic Paleustolls) or Grant-Pond Creek (fine-silty, mixed thermic Udic-Pachic Argiustolls) silt loam soil complexes. Four sets of three experimental lines were classified as very susceptible (VS), moderately susceptible (MS), intermediate (I), or tolerant (T) based on hematoxylin staining pattern, and evaluated in limed and unlimed plots as separate experiments in 1988 and 1989 . The VS group produced the fewest spikes per square meter and the lowest aboveground biomass and grain yield in the unlimed treatments; no such reductions occurred in the limed treatments. Differences in agronomic performance were found between groups of VS and MS lines, with relatively little differentiation among MS, I, and T groups. Comparison of two sister lines from the VS and T groups revealed a $12 \%$ increase in spike density, $11 \%$ increase in biomass, and a $14 \%$ increase in grain yield of the tolerant sib under acidic conditions. The two sibs performed similarly under limed conditions, except the VS line was superior in grain yield. The hematoxylin staining procedure shows promise for identifying wheat genotypes with potentially high sensitivity to acidic soils in the southern Great Plains.
\end{abstract}

$\mathrm{S}$ IL ACIDITY can be corrected by application of lime. Although lime is a relatively inexpensive material, many wheat producers in the southern Great Plains face potential production losses, if not crop failure, due to soil acidity ( $\mathrm{pH}<5.2$ ). Those producers either find the added costs of transporting lime economically unfeasible (often $\$ 25$ to 30 per ton of ECCE), or they lack landowner support to apply lime to leased land. While the use of acid tolerant cultivars may postpone the need for corrective lime applications, it is the only alternative in some situations (Foy, 1983; Kohli and Rajaram, 1988).

Because soluble Al is usually associated with the toxic effect of soil acidity, the identification of acid tolerant germplasms is often based upon some indicator of Al tolerance (Foy et al., 1965; Carver et al., 1988; Garland-Campbell and Carter, 1990). Lafever et al. (1977) related cultivar responses in acidic soil having high exchangeable $\mathrm{Al}\left(\approx 140 \mathrm{mg} \mathrm{kg}^{-1}\right)$ to measurements of root length and weight, leaf length, and shoot weight of the same cultivars grown in nutrientsolutions containing $8 \mathrm{mg} \mathrm{kg}^{-1} \mathrm{Al}$. Field responses were most consistent with root length measurements. Aluminum sensitivity in wheat has been attributed to the inability to tolerate acidic conditions in the rhi-

Dep. of Agronomy, Oklahoma State Univ., Stillwater, OK 74078. Work supported in part by the Oklahoma Wheat Res. Foundation. Published with approval of the Director of the Oklahoma Agric. Exp. Stn. as J-05945. Received 4 Feb. 1991. *Corresponding author.

Published in Crop Sci. 32:104-107 (1992). zosphere and a consequent increase in $\mathrm{Al}$ solubility (Taylor and Foy, 1985), but the primary cause may directly relate to greater uptake of $\mathrm{Al}$ in the root (Foy et al., 1967). Differences in Al uptake were also found in Hordeum vulgare L. (MacLean and Chiasson, 1966) and Gossypium hirsutum L. (Naidoo et al., 1978). Recently, Zhang and Taylor (1989) suggested an exclusion mechanism could possible reduce $\mathrm{Al}$ uptake into the symplasm of tolerant genotypes.

To visually determine the degree of $\mathrm{Al}$ uptake, or level of $\mathrm{Al}$ tolerance, wheat seedling roots are grown in nutrient solutions containing $\mathrm{Al}$ and stained with a sodium iodate-hematoxylin $\left(\mathrm{NaIO}_{3}-\mathrm{C}_{16} \mathrm{H}_{14} \mathrm{O}_{6}\right)$ solution (Polle et al., 1978). As the intensity of staining increases for a given concentration of $\mathrm{Al}$, the level of tolerance decreases. Cultivars subjected to three $\mathrm{Al}$ concentrations $(0.18,0.36$, and $0.72 \mathrm{mM} \mathrm{Al})$ can be classified into four tolerance levels, ranging from very susceptible to tolerant, according to their staining characteristics. Staining type is scored from the primary root of 1-wk-old plants as complete, partial, or no staining. A very susceptible genotype shows complete staining at all three concentrations, whereas a tolerant genotype shows either partial or no staining. The hematoxylin staining procedure is simple, facilitates screening large numbers of lines, and minimizes confounding factors inherent to field studies. Yet, its agronomic relevance to acidic field conditions has not been documented to justify its use in a selection program. Our objective, therefore, was to compare agronomic responses of wheat lines differing in hematoxylin staining pattern under naturally acidic and limed field conditions of the southern Great Plains.

\section{MATERIALS AND METHODS}

Test materials consisted of 12 experimental HRW wheat lines from the 1987 Southern Regional Performance Nursery, a uniform testing program conducted annually by USDA-ARS and state experiment stations. Genotypes were selected for varying degrees of $\mathrm{Al}$ tolerance based on visual assessment of hematoxylin-stained seedling roots in nutrient-solution culture (Carver et al., 1988). Three lines were chosen to represent each of four tolerance levels or groups: VS, MS, I, and T (Table 1). Lines were also chosen based on parentage to maximize genetic similarity among groups and thereby reduce the confounding effect of genetic differences unrelated to $\mathrm{Al}$ tolerance. For example, Amigo appeared in the pedigrees of OK82377 (VS), OK85347 (MS), TX81V5581 (MS), and TX81V66072 (T), while 'TAM W101 ' or its closely related counterpart, 'TAM W-103', appeared in the pedigrees of TX78A3345 (VS), OK85347 (MS), OK84349 (I), and TX84A7608 (T). TX78A3345 and TX84A7608 have the same pedigree, but these sib lines showed opposite responses to Al toxicity. Some experimental lines were subsequently released as cultivars, including KS82H144 (PI 506344) as 'Dodge' (Martin et al., 1988) and CO82009 as 'Lamar'.

Field experiments were conducted under limed and unlimed soil conditions on a Bethany-Kirkland silt loam com-

Abbreviations: ECCE, effective calcium carbonate equivalent; HRW, hard red winter; I, intermediate; MS, moderately susceptible; T, tolerant; VS, very susceptible. 
Table 1. Four groups of wheat genotypes differing in hematoxylin staining pattern of seedling roots.

\begin{tabular}{|c|c|c|c|}
\hline Group ${ }^{\dagger}$ & $\begin{array}{c}\text { Staining } \neq \\
\text { pattern }\end{array}$ & Entry & Pedigree \\
\hline VS & $\mathrm{CCC}$ & $\begin{array}{l}\text { OK82377 } \\
\text { TX78A3345 } \\
\text { CO820026 }\end{array}$ & $\begin{array}{l}\text { Amigo sib/2*Newton } \\
\text { MV-69-12/TAM W-103 } \\
\text { Mexican Dwarf/Baca//Vona }\end{array}$ \\
\hline MS & PCC & $\begin{array}{l}\text { OK85347 } \\
\text { TX81V5581 } \\
\text { C0830027 }\end{array}$ & $\begin{array}{l}\text { TAM W-101/Amigo } \\
\text { TX73V203*3/Amigo } \\
\text { 74CB462/Trapper//Vona }\end{array}$ \\
\hline I & PPC & $\begin{array}{l}\text { OK84349 } \\
\text { CO82009 } \\
\text { CO830034 }\end{array}$ & $\begin{array}{l}\text { Aurora/2*TAM W-101 } \\
\text { 74F878/Wings//Vona } \\
\text { CO5926//Siete Cierros/Tobari 63/ } \\
\text { 3/Baca }\end{array}$ \\
\hline $\mathrm{T}$ & NPP & $\begin{array}{l}\text { TX84A7608 } \\
\text { TX81V66072 } \\
\text { KS82H144 }\end{array}$ & $\begin{array}{l}\text { MV-69-12/TAM W-103 } \\
\text { TX71A1039-V1*3/Amigo } \\
\text { Newton sib/Arkan sib }\end{array}$ \\
\hline
\end{tabular}

†VS $=$ very susceptible, $\mathrm{MS}=$ moderately susceptible, $\mathrm{I}=$ intermediate, $\mathrm{T}=$ tolerant to $\mathrm{Al}$.

$\ddagger$ Degree of staining listed in order of response to $0.18,0.36$, and 0.72 $\mathrm{mM} \mathrm{Al}$ in nutrient-solution culture: $\mathrm{C}=$ complete staining, $\mathrm{P}=$ partial staining, and $\mathrm{N}=$ no staining.

plex at the Stillwater Agronomy Research Station in 1988 and 1989, and on a Grant-Pond Creek silt loam complex at the North Central Research Station near Lahoma, OK, in 1989. Those locations were specifically chosen for their prior history of acid-soil stress conditions. Lime (50\% ECCE) was applied at a rate of $\approx 2200 \mathrm{~kg} \mathrm{ha}^{-1}$ at least $1 \mathrm{yr}$ prior to this study to constitute the limed treatment. The 12 genotypes were assigned to four-row plots $(1.2$ by $3.0 \mathrm{~m})$ in a randomized complete-block design with four replicates in each of two fields (unlimed and limed). Plots were fertilized prior to planting according to soil-test recommendations, with attention given to consistent nutrient composition between treatments.

Due to suspected soil heterogeneity at Stillwater, three soil cores (top 15-20 cm) were collected from each plot during anthesis. The three cores were combined to determine $\mathrm{pH}$ in a $1: 1(\mathrm{w} / \mathrm{w})$ ratio of soil and $1 \mathrm{M} \mathrm{KCl}\left(\mathrm{pH}_{\mathrm{s}}\right)$ in 1988 and 1989 . Extractable $\mathrm{Al}$ in $1 \mathrm{M} \mathrm{KCl}$ was also measured in 1988 by induction coupled plasma-atomic emission spectroscopy (Thermo Jarrel Ash Crop., Franklin, MA). The total plot area in the unlimed and limed fields at Lahoma were partitioned into six blocks of $46 \mathrm{~m}^{2}$. Nine soil cores per block were combined to determine $\mathrm{pH}$ using a $1: 1(\mathrm{w} / \mathrm{w})$ ratio of soil and water $\left(\mathrm{pH}_{\mathrm{w}}\right)$.

After confirming homogeneity of error variances, analyses of variance were combined over the three locationyears (environments) for each treatment. Variation among genotypes was partitioned into components representing differences among groups according to Al tolerance level and lines within groups. Effects of groups and lines were considered fixed. Group means were compared within treatments according to Waller-Duncan's $t$-test with a $k$-ratio of 100:1 (Steel and Torrie, 1980, p. 190-191). Single-df contrasts were also made to compare means of the two sister lines.
Table 2. Soil analyses $(\bar{x} \pm \mathrm{SD})$ of unlimed and limed field plots in 1988 and 1989.

\begin{tabular}{llcrcc}
\hline Location & Treatment & Year & $n$ & $\mathrm{KCl} \mathrm{pH} \dagger$ & $\begin{array}{c}\mathrm{Al} \\
\text { concentration }\end{array}$ \\
\hline $\begin{array}{c}\text { Stillwater, } \\
\text { OK }\end{array}$ & Unlimed & 1988 & 48 & $3.8 \pm 0.1$ & $\begin{array}{c}\mathrm{mg} \mathrm{kg}^{-1} \\
\end{array}$ \\
& Limed & 1989 & 48 & $3.1 \pm 0.5$ & -3.3 \\
& 1988 & 48 & $4.5 \pm 0.2$ & $0.7 \pm 0.8$ \\
$\begin{array}{c}\text { Lahoma, } \\
\text { OK }\end{array}$ & Unlimed & 1989 & 48 & $5.0 \pm 0.2$ & - \\
& Limed & 1989 & 6 & $4.5 \pm 0.01 \dagger$ & $3.2 \pm 1.5$ \\
\hline
\end{tabular}

†Estimated values based on $\mathrm{pH}_{\mathrm{w}}$ determinations minus the expected difference between $\mathrm{pH}_{\mathrm{w}}$ and $\mathrm{pH}_{\mathrm{s}}(1.3$ units) measured in adjacent experimental plots.

\section{RESULTS AND DISCUSSION}

Our intention was to use $\mathrm{pH}$ and $\mathrm{Al}$ concentration as covariates in the analysis of variance and thereby adjust for possible soil heterogeneity at Stillwater, particularly in the unlimed treatment. Neither covariate, however, significantly reduced the error variance $(P>0.05)$; thus, unadjusted means are reported throughout. In acid soils, the $\mathrm{KCl}$ extraction generally produces $\mathrm{pH}_{\mathrm{s}}$ values one or more units less than $\mathrm{pH}_{\mathrm{w}}$ values, depending on soil type. Values of $\mathrm{pH}_{\mathrm{s}}$ at $\mathrm{La}-$ homa were estimated by subtracting the difference between $\mathrm{pH}_{\mathrm{w}}$ and $\mathrm{pH}_{\mathrm{s}}$ measured in other experiments (1.3 units) in the same field (Table 2). Values for extractable $\mathrm{Al}$ are actual means from the adjacent unlimed and limed experiments. The limed treatment in each location produced $\mathrm{pH}$ values not considered yield limiting (Johnson et al., 1988). Corresponding soil pHs in the unlimed treatments were 0.7 to 1.9 units lower, producing 10-fold increases in Al concentration in Stillwater and Lahoma.

Tiller density, measured by the number of spikes per square meter, was expected to provide an early indicator of differential Al tolerance because symptoms of $\mathrm{Al}$ toxicity are expressed early in juvenile growth of wheat (Long and Foy, 1970; Westerman, 1981; Unruh and Whitney, 1986). The analysis of variance across three unlimed environments revealed significant differences $(P<0.05)$ among groups for spike density, as well as for total aboveground yield (biomass), grain yield, and harvest index (Table 3). Group differences in spike density were not accompanied by differences in kernel number per spike and kernel weight. The same analysis of variance in the limed environments (data not shown) did not indicate significant group differences, except for spike density

Table 3. Selected mean squares from the analysis of variance across three unlimed (acid soil) environments of four groups of wheat genotypes differing in hematoxylin staining pattern.

\begin{tabular}{|c|c|c|c|c|c|c|c|}
\hline \multirow[b]{2}{*}{ Source } & \multicolumn{7}{|c|}{ Mean squares } \\
\hline & df & Spike no. $\mathrm{m}^{-2} \dagger$ & $\begin{array}{l}\text { Aboveground } \\
\text { yield } \dagger\end{array}$ & $\begin{array}{l}\text { Grain } \\
\text { yield } †\end{array}$ & $\begin{array}{l}\text { Harvest } \\
\text { index }\end{array}$ & $\begin{array}{l}\text { Kernel no. } \\
\text { spike }^{-1}\end{array}$ & $\begin{array}{c}\text { 1000-kernel } \\
\text { wt. }\end{array}$ \\
\hline Group & 3 & $37.1 * *$ & $4,054.5 * *$ & $345.2 * *$ & $22.2 * *$ & 11.8 & 11.1 \\
\hline Line/Group & 8 & $26.0^{* *}$ & $1,736.6^{* *}$ & $457.9 * *$ & $45.5^{* *}$ & $90.3 * *$ & $81.9 * *$ \\
\hline Group $\times$ Environment $($ Env) & 6 & 2.8 & $1,316.4^{* *}$ & $278.7 * *$ & $15.6^{* *}$ & 16.2 & $15.0^{* *}$ \\
\hline Line $/$ Group $\times$ Env & 16 & $7.4 * *$ & 478.0 & $127.1 * *$ & $9.8^{* *}$ & $22.0 * *$ & 8.2 \\
\hline Pooled error & 99 & 2.8 & 338.4 & 46.8 & 3.4 & 9.3 & 4.7 \\
\hline CV (\%) & & 12 & 8 & 9 & 6 & 12 & 8 \\
\hline
\end{tabular}

*.**Significant at $P=0.05$ and 0.01 , respectively

$\dagger$ Actual quantities equal reported quantity $\times 10^{3}$. 
Table 4. Average agronomic performance across three unlimed (acid soil) and across three limed environments of four groups of wheat genotypes differing in hematoxylin staining pattern.

\begin{tabular}{|c|c|c|c|c|c|c|c|}
\hline Treatment & Group $\dagger$ & $\begin{array}{l}\text { Spike } \\
\text { density }\end{array}$ & $\begin{array}{l}\text { Aboveground } \\
\text { yield }\end{array}$ & $\begin{array}{l}\text { Grain } \\
\text { yield }\end{array}$ & $\begin{array}{l}\text { Harvest } \\
\text { index }\end{array}$ & $\begin{array}{l}\text { Kernel S } \\
\text { spike }^{-1}\end{array}$ & $\begin{array}{c}\text { 1000-kernel } \\
\text { wt. }\end{array}$ \\
\hline & & spikes $\mathrm{m}^{-2}$ & $-\mathrm{kg}$ & - & $\%$ & no. & g \\
\hline $\operatorname{LSD}(k=100)$ & $\begin{array}{c}\text { VS } \\
\text { MS } \\
\text { I } \\
\text { T }\end{array}$ & $\begin{array}{r}424 \\
491 \\
442 \\
483 \\
23\end{array}$ & $\begin{array}{r}6630 \\
7000 \\
7360 \\
7310 \\
250\end{array}$ & $\begin{array}{r}2170 \\
2370 \\
2370 \\
2370 \\
96\end{array}$ & $\begin{array}{r}33.1 \\
33.7 \\
32.6 \\
32.9 \\
0.8\end{array}$ & $\begin{array}{l}25.5 \\
24.3 \\
25.5 \\
25.3 \\
\text { NS }\end{array}$ & $\begin{array}{l}27.5 \\
27.0 \\
27.7 \\
26.5 \\
\text { NS }\end{array}$ \\
\hline $\operatorname{LSD}(k=100)$ & $\begin{array}{c}\text { VS } \\
\text { MS } \\
\text { I } \\
\text { T }\end{array}$ & $\begin{array}{r}594 \\
612 \\
575 \\
624 \\
35\end{array}$ & $\begin{array}{c}7410 \\
7290 \\
7310 \\
7260 \\
\text { NS }\end{array}$ & $\begin{array}{c}2270 \\
2150 \\
2210 \\
2160 \\
\text { NS }\end{array}$ & $\begin{array}{c}30.6 \\
29.6 \\
30.3 \\
29.9 \\
\text { NS }\end{array}$ & $\begin{array}{c}24.0 \\
23.5 \\
23.9 \\
23.4 \\
\text { NS }\end{array}$ & $\begin{array}{r}26.0 \\
25.0 \\
25.7 \\
23.5 \\
0.8\end{array}$ \\
\hline
\end{tabular}

$\dagger \mathrm{VS}=$ very susceptible, $\mathrm{MS}=$ moderately susceptible, $\mathrm{I}=$ intermediate, and $\mathrm{T}=$ tolerant to $\mathrm{Al}$ based on hematoxylin staining pattern.

$(P<0.05)$ and kernel wt. $(P<0.01)$. Averaged across all traits, $93 \%$ of the total phenotypic variation in the limed environments was attributed to lines within groups. That source of variance was still significant $(P<0.01)$ for all traits in the unlimed environments (Table 3 ), but accounted for a lower average proportion of the total $(78 \%)$. Acid-soil conditions in the unlimed treatment generally produced differences among lines grouped according to Al tolerance level when those differences did not exist in the limed treatment. Most importantly, the four groups did not differ in yield potential in the limed treatment but did differ in the unlimed treatment.

Group $\times$ environment interactions in the unlimed treatment accounted for a significant component of genotype $\times$ environment interactions for several traits (Table 3), making comparisons among group means tenuous. Examination of group means within environments, however, revealed rank changes strictly among the MS, I, and T groups. Furthermore, the VS group consistently produced the fewest spikes per square meter and least biomass and grain yield among the four groups; absolute differences among the MS, I, and T groups were generally smaller in magnitude and nonsignificant. Thus, remaining discussion will focus on the average response of groups across all environments (Table 4).

The VS group produced the fewest spikes per square meter under acidic conditions (Table 4 ). Spike densities of the MS and I groups were inconsistent with their Al tolerance level. By adjusting for average spike density in the limed treatment, the greatest change among groups in relative spike density occurred between the VS and MS groups. Ratios were 0.71, 0.80, 0.77 , and 0.77 for VS, MS, I, and T groups, respectively. We could not confirm based on these data that the reduced spike density in VS lines resulted from a lower tillering capacity during early vegetative growth, or a higher tiller abortion rate during stem elongation, or both.

The VS group also produced the lowest biomass and grain yield under acidic conditions, but no differences occurred under limed conditions (Table 4). The lower grain yield of VS lines was not related to changes in kernel number per spike or kernel weight. Further increases in biomass of I and T groups compared with MS lines did not translate into higher grain yields, as those groups possessed lower harvest indices.

One unexpected outcome of this experiment was the higher average grain yield in the unlimed treatment $\left(2320 \mathrm{~kg} \mathrm{ha}^{-1}\right)$ vs. the limed treatment $\left(2200 \mathrm{~kg} \mathrm{ha}^{-1}\right)$, despite almost a $25 \%$ reduction in average spike density in the unlimed treatment. The lack of replication of treatment units (unlimed and limed) precluded statistical comparison of treatment means. The lower spike density in the unlimed treatment, however, was accompanied by numerically higher kernel number $(25$ kernels spike $\left.{ }^{-1}\right)$ and 1000 -kernel weight $(27 \mathrm{~g})$ compared with the limed treatment $\left(24\right.$ kernels spike ${ }^{-1}$ and $25 \mathrm{~g})$. Climatic conditions in 1988 and 1989 were conducive to this recovery because in no environment was drought stress sufficiently severe to cause plant death. Goldman et al. (1989) recognized the compounding effects of drought stress and $\mathrm{Al}$ toxicity on soybean (Glycine max [L.] Merr.) growth and seed yield. Another contributing factor to the observed grain yield recovery might be that soil acidity and Al toxicity in semiarid regions of the USA, including Oklahoma, are limited to the top 15 to $20 \mathrm{~cm}$ of the soil profile (Westerman, 1987). Finally, increased incidence of take-all (Gaeumannomyces graminis var. tritici) has been shown to reverse the expected increase in grain yield following lime application (Murray et al., 1987). Root and crown diseases were not monitored during this study, but have since been detected in limed treatments at the same test sites. The confounding effect of this disease pressure is especially difficult to remove due to ineffective chemical control measures and the lack of genetic resistance.

Comparison of sister lines, TX78A3345 (VS) and TX84A7608 $(\mathrm{T})$, provide an assessment of the agronomic relevance of $\mathrm{Al}$ tolerance with minimal bias caused by differences in genetic background. Their difference in tolerance was confirmed by differences in root elongation under $\mathrm{Al}$ stress in nutrient-solution culture. Four days following pulse-exposure to $0.5 \mathrm{mg}$ $\mathrm{Al} \mathrm{L}^{-1}$, the VS genotype showed no net root elongation, but the $\mathrm{T}$ genotype showed a $75 \%$ increase (J.D. Ownby, 1990, personal communication). In this study, the T genotype produced $12 \%$ more spikes, $11 \%$ more aboveground biomass, and $14 \%$ more grain yield than the VS genotype under acid-soil stress (Table 5 ). The $\mathrm{T}$ genotype also produced $25 \%$ more ker- 
Table 5. Average agronomic performance across three unlimed (acid soil) and across three limed environments of two sib lines differing in hematoxylin staining pattern.

\begin{tabular}{|c|c|c|c|c|c|c|c|}
\hline Treatment & Entry† & $\begin{array}{l}\text { Spike } \\
\text { density }\end{array}$ & $\begin{array}{l}\text { Aboveground } \\
\text { yield }\end{array}$ & $\begin{array}{l}\text { Grain } \\
\text { yield }\end{array}$ & $\begin{array}{c}\text { Harvest } \\
\text { index }\end{array}$ & $\begin{array}{l}\text { Kernels } \\
\text { spike }^{-1}\end{array}$ & $\begin{array}{c}\text { 1000-kernel } \\
\text { wt. }\end{array}$ \\
\hline & & spikes $\mathrm{m}^{-2}$ & $\longrightarrow \mathrm{kg} \mathrm{h}$ & 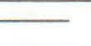 & $\%$ & no. & g \\
\hline Unlimed & $\begin{array}{l}\text { TX78A3345 (VS) } \\
\text { TX84A7608 (T) } \\
\text { F-test }\end{array}$ & $\begin{array}{c}433 \\
487 \\
*\end{array}$ & $\begin{array}{c}6580 \\
7320 \\
* *\end{array}$ & $\begin{array}{c}2210 \\
2520 \\
* *\end{array}$ & $\begin{array}{l}34.0 \\
35.1 \\
\text { NS }\end{array}$ & $\begin{array}{c}21.9 \\
27.3 \\
* *\end{array}$ & $\begin{array}{c}29.5 \\
26.9 \\
* *\end{array}$ \\
\hline Limed & $\begin{array}{l}\text { TX78A3345 (VS) } \\
\text { TX84A7608 (T) } \\
\text { F-test }\end{array}$ & $\begin{array}{l}645 \\
624 \\
\text { NS }\end{array}$ & $\begin{array}{c}8040 \\
7750 \\
\text { NS }\end{array}$ & $\begin{array}{c}2580 \\
2370 \\
*\end{array}$ & $\begin{array}{l}31.9 \\
30.7 \\
\text { NS }\end{array}$ & $\begin{array}{l}23.5 \\
25.1 \\
\mathrm{NS}\end{array}$ & $\begin{array}{l}26.3 \\
23.9 \\
\text { NS }\end{array}$ \\
\hline
\end{tabular}

*.**Significant at $P=0.05$ and 0.01 , respectively.

+VS = very susceptible, $\mathrm{T}=$ tolerant to Al based on hematoxylin staining pattern.

nels per spike, but that difference was partly negated by a $9 \%$ reduction in kernel weight. The VS genotype actually showed higher grain yield potential under limed conditions.

The hematoxylin staining procedure certainly shows promise for identifying genotypes with high sensitivity to acidic soils in the southern Great Plains. A recent survey of $\mathrm{Al}$ tolerance based on hematoxylin staining pattern classified 54\% of the sampled HRW germplasm pool as very susceptible (Carver et al., 1988), the same classification that proved to be uniquely sensitive to acid-soil conditions in this study. The level of resolution among Al-tolerance levels in the laboratory was not repeated in the field, as differences in agronomic performance were generally found only between VS and MS groups. The lack of differentiation among the MS, I, and T groups could reflect (i) an adequate tolerance level among MS genotypes to withstand surface-soil acidity in the southern Great Plains, (ii) a level of acid-soil stress insufficient in this study to distinguish among the higher tolerance levels, or (iii) factor(s) in addition to Al tolerance that govern plant response to acid-soil conditions. Future research is underway to clarify this enigma.

\section{REFERENCES}

Carver, B.F., W.P. Inskeep, N.P. Wilson, and R.L. Westerman. 1988. Seedling tolerance to aluminum toxicity in hard red winter wheat germplasm. Crop Sci. 28:463-467.

Foy, C.D. 1983. Plant adaptation to mineral stress in problem soils. Iowa State J. Res. 57:339-354.

Foy, C.D., W.H. Armiger, L.W. Briggle, and D.A. Reid. 1965. Differential aluminum tolerance of wheat and barley varieties in acid soils. Agron. J. 57:413-417.

Foy, C.D., A.L. Fleming, G.R. Burns, and W.H. Armiger. 1967. Characterization of differential aluminum tolerance among varieties of wheat and barley. Soil Sci. Soc. Am. Proc. 31:513521.

Garland-Campbell, K.A., and T.E. Carter, Jr. 1990. Aluminum tolerance in soybean: I. Genotypic correlation and repeatability of solution culture and greenhouse screening methods. Crop Sci. 30:1049-1054.
Goldman, I.L., T.E. Carter, Jr., and R.P. Patterson. 1989. Differential genotypic response to drought stress and subsoil aluminum in soybean. Crop Sci. 29:330-334.

Johnson, G., R. Westerman, and D. Minter. 1988. Liming acid soils for wheat production. Oklahoma State Univ. Ext. Facts 2240.

Kohli, M.M., and S. Rajaram (ed.) 1988. Wheat breeding for acid soils: Review of Brazilian/CIMMYT collaboration 1974 1986. CIMMYT, Mexico, D.F

Lafever, H.N., L.G. Campbell, and C.D. Foy. 1977. Differential response of wheat cultivars to Al. Agron. J. 69:563-568.

Long, L.F., and C.D. Foy. 1970. Plant varieties as indicators of aluminum toxicity in the $\mathrm{A}_{2}$ horizon of a Norfolk soil. Agron. J. 62:679-681.

MacLean, A.A., and T.C. Chiasson. 1966. Differential performance of two barley varieties to varying aluminum concentration. Can. J. Soil Sci. 46:147-153.

Martin, T.J., R.G. Sears, D.L. Wetzel, M.D. Shogren, J.R. Lawless, and M.D. Witt. 1988. Registration of 'Dodge' wheat. Crop Sci. 28:197-198.

Murray, G.M., B.J. Scott, Z. Hochman, and B.J. Butler. 1987. Failure of liming to increase grain yield of wheat and triticale in acid soils may be due to the associated increase in incidence of take-all (Gaeumannomyces graminis var. tritici. Aust. J. Exp. Agric. 27:411-417.

Naidoo, G., J. McD. Stewart, and R.J. Lewis. 1978. Accumulation sites of $\mathrm{Al}$ in snapbean and cotton roots. Agron. J. 70:489492.

Polle, E., C.F. Konzak, and J.A. Kittrick. 1978. Visual detection of aluminum tolerance levels in wheat by hematoxylin staining of seedling roots. Crop Sci. 18:823-827.

Steel, R.G.D., and J.H. Torrie. 1980. Principles and procedures of statistics. 2nd ed. McGraw-Hill Book Co., New York.

Taylor, G.J., and C.D. Foy. 1985. Mechanisms of aluminum tolerance in Triticum aestivum L. (wheat). I. Differential pH induced by winter cultivars in nutrient solutions. Am. J. Bot. 72:695-701.

Unruh, L., and D. Whitney. 1986. Soil acidity and aluminum toxicity: An important factor in winter wheat yields. Better Crops Plant Food 70 (Summer):20-22.

Westerman, R.L. 1981. Factors affecting soil acidity. Solutions 25(2):64-81.

Westerman, R.L. 1987. Soil reaction-acidity, alkalinity, and salinity. p. 340-344. In E.G. Heyne (ed.) Wheat and wheat improvement. 2nd ed. Agron. Monogr. 13. ASA, CSSA, and SSSA, Madison, WI.

Zhang, G., and G.J. Taylor. 1989. Kinetics of aluminum uptake by excised roots of aluminum-tolerant and aluminum-sensitive cultivars of Triticum aestivum L. Plant Physiol. 91:1094-1099. 